\title{
Optimizing culture conditions for the antagonistic activities of Trichoderma viride against Sclerotium rolfsii causative agent of southern blight disease of tomato
}

\author{
Ekundayo Esther Aanuoluwa ${ }^{1,2^{*}}$, Adebisi Kehinde ${ }^{2}$, Boboye Bolatito Esther ${ }^{1}$, Akinyele Bamidele Juliet ${ }^{1}$ and \\ Adetuyi Fatusa Clement ${ }^{1}$
}

${ }^{1}$ Department of Microbiology, Federal University of Technology, P. M. B. 704, Akure, Ondo State, Nigeria.
${ }^{2}$ Department of Biological Sciences, Afe Babalola University, Ado-Ekiti, Ekiti State, Nigeria. Email: esttydayo2010@yahoo.co.uk

Received 16 February 2014; Received in revised form 10 October 2014; Accepted 20 October 2014

\begin{abstract}
Aims: Sclerotium rolfsii is a pathogen of agricultural crops such as tomatoes. Trichoderma viride has been shown to control this pathogen effectively but the optimum conditions of this biocontrol agent need to be determined. This piece of research was therefore aimed at studying the conditions that could be maintained in maximizing the full potential of $T$. viride.

Methodology and results: Malt extract agar was separately supplemented with different carbon sources (glucose, sucrose, maltose, lactose, and mannitol), nitrogen sources (peptone, ammonium nitrate, zinc nitrate and sodium nitrate) as well as salts $\left(\mathrm{NaCl}, \mathrm{CaCl}_{2}, \mathrm{KI}, \mathrm{BaCl}_{2}\right)$ at different concentrations. Effect of different temperature and $\mathrm{pH}$ ranges was also evaluated. All the carbon used supported the growth of both $S$. rolfsii and $T$. viride at all concentrations. The growth of $S$. rolfsii was less than $90 \mathrm{~mm}$ at $3 \%$ of all the carbon used compared to the plates in which no carbon sources were added whereas the growth of $T$. viride was $90 \mathrm{~mm}$. There were morphological changes in the growth of both $T$. viride and $S$. rolfsii with increase in concentrations of peptone and ammonium nitrate. The greenish colour of $T$. viride was completely lost while $S$. rolfsii became fluffier. For peptone, the percentage reduction ranged from 68.52 to 63.33 while for zinc nitrate and sodium nitrate, the percentage reduction ranged from 85.19 to 80.74 and 55.00 to 43.70 respectively. Also, there was increase in antagonistic property of $T$. viride with the inclusion of salts $\left(\mathrm{NaCl}, \mathrm{CaCl}_{2}\right.$ and $\left.\mathrm{KI}\right)$ at all concentrations used. However, barium chloride was toxic to T. viride at $2-5 \%(\mathrm{w} / \mathrm{v})$. The optimum temperature and $\mathrm{pH}$ for the antagonistic property of $T$. viride appeared to be $37^{\circ} \mathrm{C}$ and 6.0 respectively.

Conclusion, significance and impact of study: Inclusion of different carbon, nitrogen and salts increased the antagonistic activities of $T$. viride against $S$. rolfsii although lactose appeared to be the best carbon source while zinc nitrate and $\mathrm{CaCl}_{2}$ were the best nitrogen and salt respectively. Barium chloride was toxic to $T$. viride at $2-5 \%(\mathrm{w} / \mathrm{v})$.
\end{abstract}

Keywords: Sclerotium rolfsii, Trichoderma viride, antagonistic activities, optimum condition

\section{INTRODUCTION}

Sclerotium rolfsii Sacc. is a soil borne plant pathogen of a wide range of agricultural and horticultural crops (Darakhshanda et al., 2007). Sclerotium rolfsii is mainly found in warm regions where it causes root rot, stem rot, wilt and foot rot (Domsch et al., 1980; Farr et al., 1989). This organism is pathogenic to a number of cultivated and non-cultivated plants but rarely on cereals (Sarma, 2002; Maurya et al., 2007) and causes serious yield loss in crops of high economic importance (Maurya et al., 2010). The crops that are mostly affected by $S$. rofsii include soybean, peanut, sugarbeet, pepper, tomato and potato while sorghum, wheat, rice, lentil, betelvine, alfalfa, cotton, sugarcane, tobacco, sunhemp, sunflower, chrysanthemum, gladiolus and other ornamental species are less affected (Ansari, 2005). The development of sclerotia is greatly influenced by both living and non living factors such as temperature and $\mathrm{pH}$ (Ellil, 1999; Sarma, 2002).

Fungal diseases have been controlled by the application of large quantities of chemical fungicides. However, their extensive use causes serious pollution problem in the environment (Raghunathan and Divakar, 1996). Therefore, there is the need for an alternative (Zegeye et al., 2011).

"A number of pythopathogenic fungi such as Rhizoctonia solani, Pythium aphanidermatium, Fusarium oxysporum, F. culmorum, Gaeumannomyces graminis var. tritici, Sclerotium rolfsii, Phytophthora cactorum, Botrytis cinerea and Alternaria spp. have been effectively controlled by Trichoderma species" (Jones and Stewart, 1997; Kucuk and Kivanc, 2003; Dolatabadi et al., 2011). Trichoderma species are known to secret extracellular 
chitinase, cellulase and $\beta-1,3$-glucanase which break which facilitate its penetration into the cytoplasm of the target fungi (Cruz et al., 1995).

Other mechanisms of action of Trichodema species include production of antifungal agents such as gliotoxin, mycoparasitism, competition for nutrients or space, tolerance to stress, among others (Harman, 2000). Although there are several publications on the antagonistic activities of $T$. viride as well as effect of carbon and nitrogen sources on the mycelial growth and weight of $T$. viride, there is little or no information on the effects of these parameters on its antagonistic properties against $S$. rolfsii. This study was therefore investigated to ascertain positive effect of different carbon, nitrogen and salts sources on the antagonistic potentials of $T$. viride against $S$. rolfsii as well as temperature and $\mathrm{pH}$.

\section{MATERIALS AND METHODS}

Trichoderma viride was collected from the Department of Microbiology, Federal University of Technology, Akure (FUTA). This isolate was obtained from yellow maize cob on potato dextrose agar. Sclerotium rolfsii was collected from the Department of Crop Soil and Pest Management, FUTA, Akure.

\section{Effect of carbon and nitrogen sources on antagonistic properties of $T$. viride}

The dual culture technique was used to determine the ability of $T$. viride to inhibit mycelial growth of $S$. rolfsii as affected by different carbon and nitrogen sources according to the method of Gomathi and Ambikapathy (2011).

\section{Effect of carbon sources}

For the carbon source assay, malt extract agar was supplemented with different carbon sources viz: glucose, sucrose, maltose, mannitol and lactose separately at three concentrations viz $1 \%, 2 \%$ and $3 \%(\mathrm{w} / \mathrm{v})$. Effect of the various carbon sources on the antagonistic activities of $T$. viride was conducted using the previously described method.

\section{Effect of nitrogen sources}

Malt extract agar was supplemented on separate Petri dishes with the following nitrogen sources: ammonium sulphate, sodium nitrate, peptone and zinc nitrate at three different concentrations viz $1 \%, 2 \%$ and $3 \%(w / v)$. Effect of the various nitrogen sources on the antagonistic activities of $T$. viridae was conducted using the previously described method.

\section{Effect of salt concentration on the antagonistic properties of $T$. viride}

Five different concentrations $(1,2,3,4,5 \%(w / v)$ of the following salts: sodium chloride, barium chloride, calcium chloride and potassium iodide were used to determine the effect of salt on the antagonistic properties of $T$. viride. Malt extract agar supplemented various concentrations of the salt before sterilization. Effect of salt concentration on the antagonistic activities of $T$. viride was conducted using the dual technique previously described method.

Effect of oxygen on the antagonistic activities of $T$. viride

The dual culture technique was used but incubation was done in an anaerobic jar at $25^{\circ} \mathrm{C}$ for 5 days. Two sets of control were done; plates containing Trichoderma alone and $S$. rolfsii alone.

Effects of $\mathrm{pH}$ and temperature on antagonistic properties of $T$. viride

\section{Effect of $\mathrm{pH}$}

Malt dextrose agar with $\mathrm{pH}$ levels of $3,6,7,9,12$ were poured into Petri dishes and a $7 \mathrm{~mm}$ plug from the margin of actively growing colony of $T$. viride and $S$. rolfsii were placed in opposite direction and were incubated at $25^{\circ} \mathrm{C}$ for 5 days (Ghildiyal and Pandey, 2008). Percentage reduction of the mycelial growth of $S$. rolfsii was calculated according to the method previously described.

\section{Effect of temperature}

Seven $\mathrm{mm}$ plugs from margins of actively growing colonies of $T$. viridae and $S$. rolfsii were placed in opposite direction on sterile malt extract agar. The Petri dishes were then incubated at various temperatures, viz: $4,25,37$ and $50{ }^{\circ} \mathrm{C}$ for 5 days (Ghildiyal and Pandey, 2008). The percentage inhibition was calculated using this formula (Gomathi and Ambikapathy, 2011).

Percentage mycelia growth inhibition of $S$. rolfsii

$=\frac{\mathrm{C} 2-\mathrm{C} 1}{\mathrm{C} 2} \times 100$

Where C2: Growth of $S$. rolfsii without T. viride C1: Growth of $S$. rolfsii and T. viride

\section{RESULTS}

\section{Effect of carbon sources on the antagonistic property of $T$. viride}

All the carbon sources (sucrose, maltose, lactose, glucose and mannitol) used supported the growth of the test fungus and antagonist ( $T$. viride) at all concentrations. Sclerotium rolfsii was able to overgrow $T$. viride of all the carbon sources except lactose at all concentrations. However, it was observed that with increase in incubation period, there was lysis of the mycelium of $S$. rolfsii by $T$. viride. The growth of $S$. rolfsii was less than $90 \mathrm{~mm}$ at $3 \%$ of all the carbon used compared to the plates in which no carbon sources were added whereas the growth of 


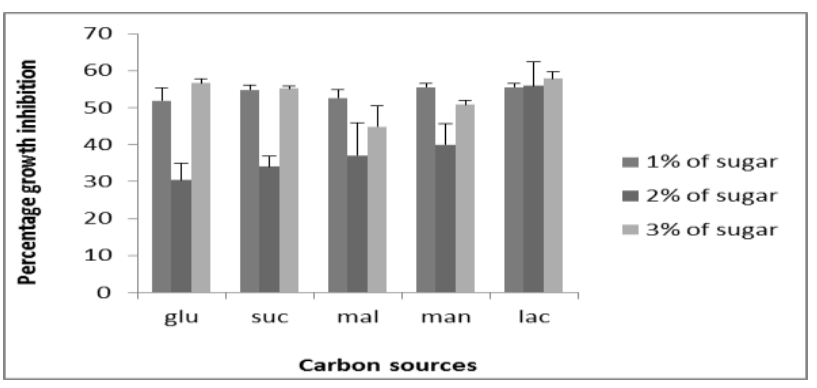

Figure 1: Effect of different carbon sources on the percentage growth inhibition of $S$. rolfsii by $T$. viride on malt extract agar at $25{ }^{\circ} \mathrm{C}$ on day 5. Glu, Glucose; Suc, Sucrose; Mal, Maltose; Man Mannitol; Lac, Lactose.

Trichoderma was $90 \mathrm{~mm}$. The percentage reduction of the mycelial growth of $S$. rolfsii is shown in Figure 1.

\section{Effect of nitrogen sources on the antagonistic property of $T$. viride}

There were morphological changes in the growth of both $T$. viride and $S$. rolfsii with increase in concentrations of all the nitrogen sources. The greenish colour of $T$. viride was completely lost while $S$. rolfsii became fluffier. The growth of $S$. rolfsii was retarded with increased concentration of nitrogen while $T$. viride was not affected. Percentage growth inhibition of $S$. rolfsii by $T$. viride is shown in Table 1.

Effect of variation in salt concentration on the antagonistic property of $T$. viride

It was observed that there were changes in the morphological characteristics of $T$. viride with increase in salt concentration. However, there was reduction in the growth of $S$. rolfsii from 3 to $5 \%$ and the fluffy nature of this fungus. The growth of $S$. rolfsii was greatly reduced at $4 \%$ compared to other concentrations on sodium chloride. The growth of $T$. viride was completely inhibited from 2 to $5 \%$ of barium chloride (Figure 2). The percentage reduction of $S$. rolfsii by $T$. viride under different concentrations of the selected salts is shown in Figures 35 .

\section{Effect of oxygen on the antagonistic property of $T$. viride}

Trichoderma viride was also antagonistic to $S$. rolfsii when incubated anaerobically at $25{ }^{\circ} \mathrm{C}$ with percentage inhibition of 58.89. However, there was inhibition of conidial formation of Trichoderma viride but $S$. rolfsii grew profusely even in this condition. It was also observed that when $T$. viride was incubated aerobically afterwards, there was formation of conidia.

Table 1: Comparative influence of different nitrogen sources on the antagonistic properties of $T$. viride against $S$. rolfsii.

\begin{tabular}{|c|c|c|c|c|c|c|}
\hline \multirow{3}{*}{$\begin{array}{l}\text { Nitrogen } \\
\text { sources }\end{array}$} & \multicolumn{6}{|c|}{$\begin{array}{l}\text { Mycelial growth and percentage reduction of } S \text {. rolfsii with increase in concentration of nitrogen } \\
\text { sources }\end{array}$} \\
\hline & \multicolumn{3}{|c|}{ Mycelial growth (mm) } & \multicolumn{3}{|c|}{ Percentage reduction of $S$. rolfsii } \\
\hline & $1 \%(w / v)$ & $2 \%(w / v)$ & $3 \%(w / v)$ & $1 \%(w / v)$ & $2 \%(w / v)$ & $3 \%(w / v)$ \\
\hline Sodium nitrate & $28.33 \pm 0.58$ & $27.33 \pm 2.89$ & $25.33 \pm 4.98$ & $55.00 \pm 1.85^{\mathrm{C}}$ & $52.87 \pm 0.64^{\mathrm{C}}$ & $43.70 \pm 1.28^{\mathrm{C}}$ \\
\hline Zinc nitrate & $13.33 \pm 1.53$ & $16.33 \pm 3.21$ & $17.33 \pm 4.93$ & $85.19 \pm 1.70^{a}$ & $81.85 \pm 3.57^{\mathrm{a}}$ & $80.74 \pm 5.49^{a}$ \\
\hline Peptone & $28.33 \pm 1.16$ & $30.67 \pm 0.58$ & $33.00 \pm 3.61$ & $68.52 \pm 1.28^{b}$ & $65.93 \pm 0.64^{b}$ & $63.33 \pm 4.01^{\mathrm{b}}$ \\
\hline $\begin{array}{l}\text { Ammonium } \\
\text { nitrate }\end{array}$ & $15.33 \pm 2.30$ & $14.33 \pm 0.58$ & $28.33 \pm 2.08$ & $82.96 \pm 2.57^{a}$ & $84.07 \pm 0.64^{a}$ & $68.52 \pm 2.31^{b}$ \\
\hline
\end{tabular}

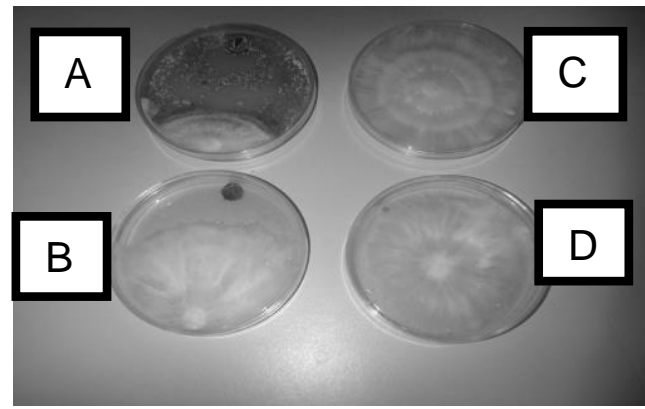

Figure 2: Effect of barium chloride on the antagonistic property of $T$. viride against $S$. rolfsii. A, Growth of $T$. viride and S. rolfsii at $1 \%$ of barium chloride; B, Growth of T. viride and S. rolfsii at $2 \%$ of barium chloride; C, Growth of $S$. rolfsii at $1 \%$ of barium chloride; D, Growth of $S$. rolfsii at $2 \%$ of barium chloride.

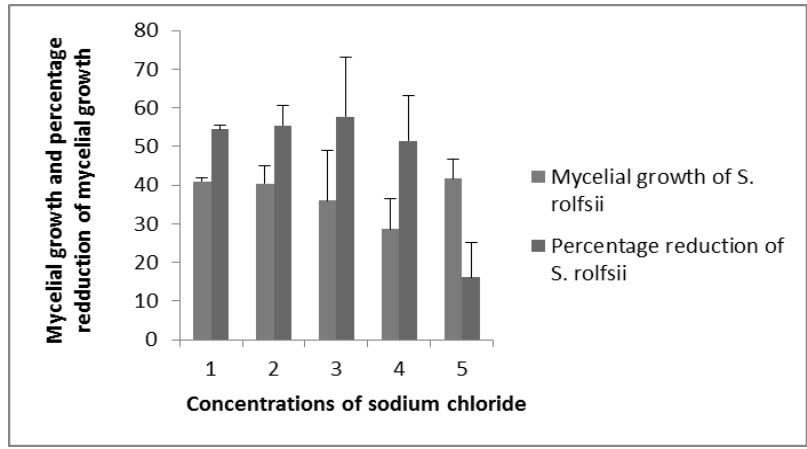

Figure 3: Effect of sodium chloride on the antagonistic property of $T$. viride against $S$. rolfsii at $25{ }^{\circ} \mathrm{C}$ on malt extract agar. 1, $1 \%$ sodium chloride; $2,2 \%$ sodium chloride; 3 , $3 \%$ sodium chloride; 4 , $4 \%$ sodium chloride; 5 , $5 \%$ sodium chloride. 


\section{Effect of temperature on the antagonistic property of T. viride}

The growth rate of $S$. rolfsii was greatly reduced at $4{ }^{\circ} \mathrm{C}$ and $37^{\circ} \mathrm{C}$. However, $T$. viride grew well at $37^{\circ} \mathrm{C}$ but there was inhibition in its conidiation and growth rate at $4{ }^{\circ} \mathrm{C}$ Neither $T$. viride nor $S$. rolfsii grew at $50^{\circ} \mathrm{C}$. There were significant differences in the antagonistic property of $T$. viride (Table 2).

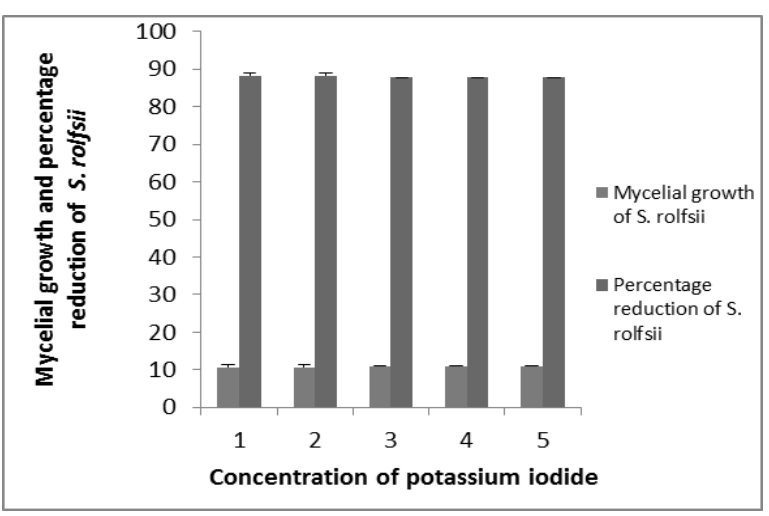

Figure 4: Effect of potassium iodide on the antagonistic property of $T$. viride against $S$. rolfsii at $25{ }^{\circ} \mathrm{C}$ on malt extract agar. 1, $1 \%$ potassium iodide; 2, $2 \%$ potassium iodide; $3,3 \%$ potassium iodide; $4,4 \%$ potassium iodide; 5 , $5 \%$ potassium iodide.

\section{Effect of $\mathrm{pH}$ on the antagonistic property of $T$. viride}

Sclerotium rolfsii was able to grow at $\mathrm{pH} 3,6,7,9$ but the growth was hampered at $\mathrm{pH} 12$. The antagonistic property of $T$. viride was only observed at $\mathrm{pH} 3,6$ and 7 . Neither $T$. viride nor $S$. rolfsii was able to overgrow each other at $\mathrm{pH}$ 12 (Table 3).

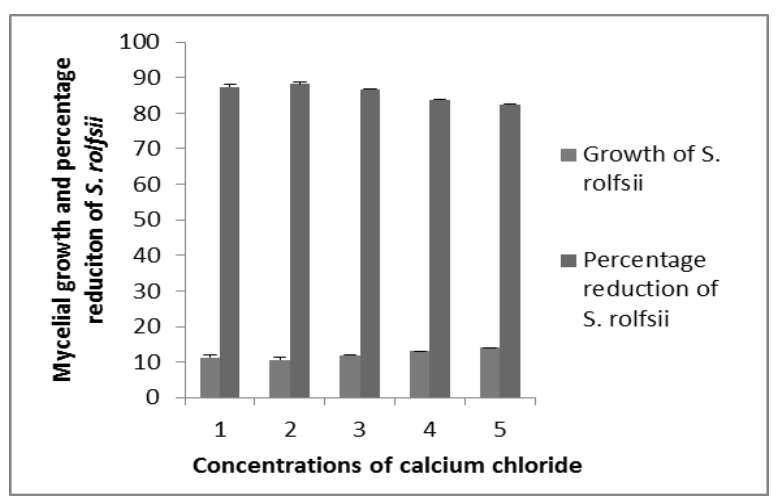

Figure 5: Effect of calcium chloride on the antagonistic property of $T$. viride against $S$. rolfsii at $25{ }^{\circ} \mathrm{C}$ on malt extract agar. 1, $1 \%$ calcium chloride; 2, $2 \%$ calcium chloride; 3, 3\% calcium chloride; $4,4 \%$ calcium chloride; $5,5 \%$ calcium chloride.

Table 2: Effect of temperature on the antagonistic property of $T$. viride against $S$. rolfsii on MEA.

\begin{tabular}{llll}
\hline Temperature $\left({ }^{\circ} \mathrm{C}\right)$ & $\begin{array}{l}\text { Mycelial growth of Trichoderma } \\
\text { viride }(\mathrm{mm})\end{array}$ & $\begin{array}{l}\text { Mycelial growth of } \\
\text { Sclerotium rolfsii }(\mathrm{mm})\end{array}$ & $\begin{array}{l}\text { Percentage reduction of } \\
\text { S. rolfsii over control }\end{array}$ \\
\hline 4 & $25.00 \pm 0.00$ & $10.00 \pm 0.00$ & 0.00 \\
25 & $43.33 \pm 2.89$ & $35.00 \pm 4.58$ & $41.67 \pm 7.67$ \\
37 & $48.67 \pm 3.22$ & $41.33 \pm 3.22$ & $36.41 \pm 4.94$ \\
50 & 0.00 & 0.00 & 0.00 \\
\hline
\end{tabular}

Table 3: Effect of $\mathrm{pH}$ on the antagonistic property of $T$. viride against $S$. rolfsii.

\begin{tabular}{llll}
\hline $\mathrm{pH}$ range & Mycelial reduction of $T$. viride & $\begin{array}{l}\text { Mycelial reduction of } S . \\
\text { rolfsii }\end{array}$ & $\begin{array}{l}\text { Percentage inhibition of } \\
\text { S. rolfsii over control }\end{array}$ \\
\hline 3 & $54.00 \pm 3.46^{\mathrm{a}}$ & $36.00 \pm 3.46^{\mathrm{b}}$ & $20.00 \pm 7.70^{\mathrm{c}}$ \\
6 & $59.33 \pm 1.16^{\mathrm{a}}$ & $30.67 \pm 1.16^{\mathrm{c}}$ & $40.37 \pm 6.29^{\mathrm{a}}$ \\
7 & $56.00 \pm 1.00^{\mathrm{a}}$ & $34.00 \pm 1.00^{\mathrm{b}}$ & $29.62 \pm 2.46^{\mathrm{b}}$ \\
9 & $35.00 \pm \pm 5.00^{\mathrm{b}}$ & $49.33 \pm 1.16^{\mathrm{a}}$ & $-2.13 \pm 3.69^{\mathrm{a}}$ \\
12 & $15.33 \pm 0.58^{\mathrm{c}}$ & $25.33 \pm 0.58^{\mathrm{a}}$ & $15.56 \pm 1.93^{\mathrm{c}}$ \\
\hline
\end{tabular}

\section{DISCUSSION}

Trichoderma viride grew well on all the carbon sources. Application of additional carbon source did enhance the antifungal activity. Similar observation has been made by Sesan and Oancea (2005). Chovanec et al. (2001) also observed conidiation in $T$. viride cultures grown on 30 out of 32 carbon sources. Antagonists' mode of action might be a combination among competitive exclusion, preemptive colonization and the production of anti-fungal substances (Nalisha et al., 2006).

Trichoderma viride was tolerant to higher concentration of $\mathrm{NaCl}, \mathrm{CaCl}_{2}$ and $\mathrm{KI}$ although there was colour change compared to the medium unsupplemented with salts. Most Trichoderma strains used as biofungicides have low osmotolerance potentials (Mohamed and Haggag, 2006). Environmental factors associated with climate change, especially temperature and soil salinity, may influence plant pathogens, 
biocontrol agents, and mechanisms of their interactions (Gal-Hemed et al., 2011). High salinity may increase the severity of diseases caused by a variety of plant pathogens (Hasegawa et al., 2000; Triky-Dotan et al., 2005), and the search for new Trichoderma strains capable of overcoming extreme environmental conditions is timely. Mohamed and Haggag (2006) reported that $T$. harzianum is sensitive to high concentration of salt contrary to the present work. Gal-Hemed et al. (2011) observed that Trichoderma atroviride and T. asperelloides exhibited a very good growth adaptation to saline environments in vitro and they can therefore be used as biological control agents of plant growth in saline soils. Ghildiyal and Pandey (2008) also observed that $T$. harzianum, T. koningii and T. viride isolated from soil samples of glacier sites in high altitudes of Indian Himalaya could tolerate salt concentration up to $5 \%(\mathrm{w} / \mathrm{v})$. Fungi have been shown to develop extrusion systems to keep levels of intracellular sodium below concentrations toxic to the cell (Gunde-Cimerman et al., 2009). Furthermore, adaptation to higher salt concentrations can be used to reduce the probability of fungal/bacterial contamination in Trichoderma stocks intended for liquid formulations in the on-site cultivation of strains (Harman et al., 2010). However, $\mathrm{BaCl}_{2}$ was toxic to T. viride from concentration $2-5 \%$. Knowledge of the prevalence of environmental conditions, both climatic and edaphic, in the habitat of a given organism may be useful for exploitation of the potential applications associated with the organism (Ghildiyal and Pandey, 2008). Certain strains of Trichoderma sp. including $T$. viride are known to be restricted to the areas identified by low temperature. There was reduction in growth of both $T$. viride and $S$. rolfsii at $4{ }^{\circ} \mathrm{C}$ though the growth of $T$. viride was higher.

The growth of $T$. viride was least at $\mathrm{pH} 12$. Sesan and Oancea (2005) observed that $T$. hiazianum showed the poorest growth at $\mathrm{pH} 13$ while the best growth was at 4.05.5. However, Ghildiyal and Pandey (2008) observed optimum $\mathrm{pH}$ of Trichoderma species to be 5.5. The optimum $\mathrm{pH}$ in this research was 6.0.

\section{CONCLUSION}

There was increase in the antagonistic activities of $T$. viride supplemented with various carbon and nitrogen sources. Trichoderma viride was halotolerant to $\mathrm{NaCl}, \mathrm{KI}$ and $\mathrm{CaCl}_{2}$ but halosensitive to $\mathrm{BaCl}_{2}$ from $2-5 \%$. The optimum temperature and $\mathrm{pH}$ for antagonistic activities of T. viride was $37^{\circ} \mathrm{C}$ and $\mathrm{pH} 6$.

\section{REFERENCES}

Ansari, M. M. (2005). Growth, survival, perpetuation and pathogenic variability of Sclerotium rolfsii, a polyphagus pathogen: A review. Journal of Oilseeds Research 22, 240-244.

Chovanec, P., Hudecová, D. and Varecka, L. (2001). Vegetative growth, aging- and light induced conidiation of Trichoderma viride cultivated on different carbon sources. Folia Microbiology (Praha) 46, 417-422.
Cruz, L., Pinter-Toro, J. A., Benitez, T. and Llobell, A. (1995). Purification and characterization of an endo-b1,3-glucanase from Trichoderma harzianum that is related to its mycoparasitism. Journal of Bacteriology 177, 1864-1877.

Darakhshanda, K. F., Azam, F., Hassan, A., Ansar, M., Asad, M. J. and Khanum, A. (2007). Comparative growth, morphological and molecular characterization of indigenous Sclerotium rolfsii strains isolated from different locations of Pakistan. Pakistan Journal of Botany 39(5), 1849-1866.

Dolatabadi, K. H., Goltapeh, E. M., Varma, A. and Rohani, N. (2011). In vitro evaluation of arbuscular mycorrhizal-like fungi and Trichoderma species against soil borne pathogen. Journal of Agricultural Technology 7(1), 73-84.

Domsch, K. H., Gams, W. and Anderson, T. H. (1980). Compendium of Soil Fungi. Vol 1 Academic Press, London, UK.

Ellil, A. H. A. A. (1999). Oxidative stress in relation to lipid peroxidation, sclerotial development and melanin production by S. rolfsii. Journal of Phytopathology 147, 561-566.

Farr, D. F., Bills, G. F., Chamuris, G. P. and Rossman, A. Y. (1989). Fungi on plant and plant products in the United States. American Phytophythological Society, APS Press, St. Paul, Minnesota, USA.

Gal-Hemed, I., Atanasova, L., Komon-Zelazowska, M., Irina, S., Druzhinina, I. S., Viterbo, A. and Yarden, O. (2011). Marine isolates of Trichoderma spp. as potential halotolerant agents of biological control for Arid-Zone Agriculture. Applied and Environmental Microbiology 77(15), 5100-5109.

Ghildiyal, A. and Pandey, A. (2008). Isolation of cold tolerant antifungal strains of Trichoderma sp. from glacial sites of Indian Himalayan region. Research Journal of Microbiology 3, 559-564.

Gomathi, S. and Ambikapathy, V. (2011). Antagonistic activity of fungi against Pythium debaryanum (Hesse) isolated from Chilli field soil. Advances in Applied Science Research 2(4), 291-297.

Gunde-Cimerman, N., Ramos, J. and Plemenitaš, A. (2009). Halotolerant and halophilic fungi. Mycological Research 113, 1231-1241.

Harman, G. E., Obregón, M. A., Samuels, G. J. and Lorito, M. (2010). Changing models for commercialization and implementation of biocontrol in the developing and the developed world. Plant Diseases 94, 928-939.

Harman, G. E. (2000). Myths and dogmas of biocontrol changes in perceptions derived from research on Trichoderma harzianum T-22. Plant Diseases 84, 377393.

Hasegawa, P. M., Bressan, R. A., Zhu, J. K. and Bohnert, H. J. (2000). Plant cellular and molecular responses to high salinity. Annual Review of Plant Physiology and Plant Molecular Biology 51, 463-499.

Jones, E. E. and Stewart, A. (1997). Biological control of Sclerotinia minor in lettuce using Trichoderma species. 
Proceedings of New Zealand Plant Protection Conference 50, 154-158.

Kucuk, C. and Kivanc, M. (2003). Isolation of Trichoderma spp. and determination of their antifungal, biochemical and physiological features. Turkish Journal of Biology 27, 247-253.

Maurya, S., Singh, D. P., Singh, U. P. and Srivastava, J. S. (2007). Plant growth promotion and management of collar rot of Chickpea (Cicer arietinum) by mycelial protein of Sclerotium rolfsii. Archives of Phytopathology and Plant Protection 42(10), 967-978.

Maurya, S., Singh, U. P., Singh, R., Singh, A. and Singh, H. B. (2010). Role of air and light in sclerotial development and basidiospore formation in Sclerotium rolfsii. Journal of Plant Protection Research 50(2), 206-209.

Mohamed, H. A. A. and Haggag, W. M. (2006). Biocontrol potential of salinity tolerant mutants of Trichoderma harzianum against Fusarium oxysporum. Brazilian Journal of Microbiology 37(2), 181-191.

Nalisha, I., Muskhazli, M. and Nor Farizan, T. (2006). Production of bioactive compounds by Bacillus subtilis against Sclerotium rolfsii. Malaysian Journal of Microbiology 2(2), 19-23.

Raghunathan, V. and Divakar, B. J. (1996). Integrated pest management strategies. In: Molecular Biology of the Biological Control of Pests and Disease of Plants. Gunasekaran, M. and Weber, D. J. (eds.). CRC Press, Florida. pp. 191-194.

Sarma, B. K. (2002). Studies of variability, sexual sage production and control of $S$. rolfsii Sacc., the causal agent of collar rot of chickpea (Cicer arietinum). Ph.D. Thesis, Department of Mycology and Plant Pathology, Institute of Agricultural Sciences, Banaras Hindu University, Varanasi, India. pp. 198.

Sesan, E. T. and Oancea, F. (2010). Trichoderma viride Pers. - Experimental model for biological and biotechnological investigations of mycromyceta with importance in obtaining plant protection bioproducts. Journal of Plant Development 17, 49-62.

Triky-Dotan, S., Yermiyahu, U., Katan, J. and Gamliel, A. (2005). Development of crown and root diseases of tomato under irrigation with saline water. Phytopathology 95, 1438-1444.

Zegeye, W. D., Santhanam, A., Gorfu, D., Tessera, M. and Kassa, B. (2011). Biocontrol activity of Trichoderma viride and Pseudomonas fluorescens against Phytophthora infestans under green house conditions. Journal of Agricultural Technology 7(6), 1589-1602. 